PRACE NAUKOWE UNIWERSYTETU EKONOMICZNEGO WE WROCLAWIU

Wyzwania dla spójności Europy -

ISSN 1899-3192

gospodarka, zrównoważony rozwój, konkurencyjność

e-ISSN 2392-0041

\title{
Maria Bucka
}

Uniwersytet Opolski

e-mail: mbucka@uni.opole.pl

\section{WSPARCIE ROZWOJU KLASTRÓW W POLSCE \\ W PERSPEKTYWIE FINANSOWEJ 2014-2020}

\section{SUPPORT FOR THE DEVELOPMENT OF CLUSTERS IN POLAND \\ IN THE 2014-2020 FINANCIAL PERSPECTIVE}

DOI: $10.15611 /$ pn.2017.466.06

JEL Classification: A11, A19, B12

\begin{abstract}
Streszczenie: Klastry stanowią istotny element każdej gospodarki. Obecność struktur klastrowych w gospodarce świadczy bowiem o poziomie jej rozwoju, a także wskazuje na jej potencjał oraz dalsze perspektywy rozwojowe. Ze względu na różnorodność struktur klastrowych nie ma dla wszystkich jednolitego zestawu instrumentów wspierających ich rozwój. Konieczne jest stosowanie różnych, odpowiednio dostosowanych do danego typu klastra instrumentów. Celem opracowania jest przedstawienie możliwości uzyskania przez klastry dofinansowania w ramach budżetu na lata 2014-2020.
\end{abstract}

Slowa kluczowe: klaster, polityka klastrowa, programy operacyjne, konkurencyjność, internacjonalizacja, polityka spójności.

Summary: Clusters are an important part of any economy. The presence of cluster structures in the economy shows the level of its development, and points to its potential and further development prospects. Due to the diversity of cluster structures, there is not a uniform set of instruments for every economy to support their development. It is necessary to use different instruments, which are tailored to a particular type of cluster. The aim of the study is to present the possibility of clusters co-financing in the 2014-2020 financial perspective.

Keywords: cluster, cluster policy, operational programs, competitiveness, internationalization, cohesion policy.

\section{Wstęp}

Wzrost zainteresowania rozwojem klastrów i ich wpływem na poprawę warunków funkcjonowania przedsiębiorstw oraz całych terytoriów, na których są zlokalizowane, spowodował, że stanowią one szczególny obiekt zainteresowania władz publicz- 
nych zarówno na szczeblu krajowym, regionalnym, jak i lokalnym. Prowadzona przez władze publiczne polityka rozwoju oparta o klastry ma pomóc przedsiębiorstwom w zwiększaniu ich pozycji konkurencyjnej. Coraz częściej klastry występują w działalności opartej na zaawansowanych technologiach. Z tego względu wspieranie klastrów jest także istotnym elementem polityki innowacyjnej, polityki naukowo-technologicznej. Ze względu na różnorodność struktur klastrowych nie ma dla wszystkich jednolitego zestawu instrumentów wspierających ich rozwój. Konieczne jest stosowanie różnych instrumentów, odpowiednio dostosowanych do danego typu klastra.

Celem opracowania jest przedstawienie możliwości uzyskania przez klastry dofinansowania w ramach budżetu na lata 2014-2020. Dla realizacji celu wykorzystano dostępne materiały źródłowe i badanie wtórne dokumentów źródłowych i statystycznych, krajowych oraz zagranicznych. Przeprowadzone badania umożliwiły dokonanie interpretacji metodą analizy, porównania i dedukcji.

\section{Definicja klastra - polityka klastrowa}

Polityka klastrowa ma na celu stymulowanie rozwoju klastrów. Dla kreowania polityki klastrowej oraz udzielania wsparcia rozwoju klastrów niezbędne jest przyjęcie definicji wyznaczającej zakres pojęcia klaster. Klastry definiuje się, jako „geograficzne skupiska wzajemnie powiązanych firm, wyspecjalizowanych dostawców, jednostek świadczących usługi, firm działających w pokrewnych sektorach i związanych znimi instytucji w poszczególnych dziedzinach, jednocześnie współdziałających i konkurujących ze sobą" [Porter 2000]. Z definicji wynika, że podmioty gospodarcze działające w klastrze są niezależne, konkurują między sobą i jednocześnie w niektórych obszarach współpracują.

W Polsce pojęcie klastra zostało zdefiniowane dla potrzeb wsparcia i skierowania środków finansowych na ich rozwój. W Rozporządzeniu Ministra Gospodarki [2006] w sprawie udzielania przez Polską Agencję Rozwoju Przedsiębiorczości pomocy finansowej niezwiązanej z programami operacyjnymi klaster zdefiniowany został jako przestrzenna i sektorowa koncentracja podmiotów działających na rzecz rozwoju gospodarczego lub innowacyjności, skupiająca najmniej 10 przedsiębiorców wykonujących działalność gospodarczą na terenie jednego lub kilku sąsiednich województw, konkurujących i współpracujących w tych samych lub pokrewnych branżach oraz powiązanych rozbudowaną siecią relacji o formalnym i nieformalnym charakterze, przy czym co najmniej połowę podmiotów funkcjonujących w ramach klastra stanowią przedsiębiorcy.

Polityka klastrowa definiowana jest jako zespół działań i instrumentów wykorzystywanych przez władze różnych szczebli do podnoszenia poziomu konkurencyjności gospodarki poprzez stymulowanie rozwoju istniejących bądź tworzeniu nowych systemów klastrowych przede wszystkim na poziomie regionalnym [Brodzi- 
cki i in. 2004]. Polityka klastrowa może być pojmowana w węższym i szerszym zakresie. W węższym zakresie obejmuje wspieranie koordynatorów klastra, których funkcjonowanie przyczynia się do rozwoju danego skupiska podmiotów gospodarczych i instytucji otoczenia. Koordynatorem klastra jest podmiot, który organizuje i animuje rozwój interakcji, powiązań i współpracy w klastrze, a także świadczy wyspecjalizowane usługi na rzecz firm i innych podmiotów działających w danym skupisku [Dzierżanowski 2006]. W szerszym zakresie obejmuje wiele różnych polityk (polityka przemysłowa, polityka innowacyjna, polityka naukowo-technologiczna itp.) i instrumentów, które w sposób skoordynowany wspierają rozwój klastrów [Dzierżanowski 2006]. W polityce klastrowej przyjęto trójstopniowy rozkład klastrów:

- Kluczowe Klastry Krajowe.

- Kluczowe Klastry Regionalne.

- Klastry Lokalne.

Kluczowe Klastry Krajowe mają istotne znaczenie dla gospodarki kraju i wysokiej konkurencyjności międzynarodowej oraz posiadają znaczący potencjał naukowo-technologiczny. Klastry te są wybierane na poziomie krajowym, m.in. w oparciu o kryteria dotyczące masy krytycznej, potencjału rozwojowego i innowacyjnego, dotychczasowej i planowanej współpracy oraz doświadczenia i potencjału koordynatora.

Kluczowe Klastry Regionalne to klastry o największym potencjale konkurencyjnym i znaczeniu dla gospodarki regionu, powiązane i konkurencyjne w skali regionu oraz wpisujące się $\mathrm{w}$ regionalne inteligentne specjalizacje. Kategoria inteligentnych specjalizacji związana jest z krajowymi i regionalnymi strategiami innowacyjnymi, które zakładają uzyskanie przewagi konkurencyjnej poprzez syntezę mocnych stron w zakresie badań naukowych i innowacyjnych z potrzebami biznesowymi w celu wykorzystania pojawiających się możliwości i rozwoju rynku. [Rozporządzenie... 2013]. Ich celem jest spójne i jak najlepsze wykorzystanie możliwości rozwoju rynkowego, przy jednoczesnym unikaniu dublowania i fragmentacji wysiłków. Krajowe inteligentne specjalizacje zostały zapisane w dokumencie Program Rozwoju Przedsiębiorstw, Krajowa Inteligentna Specjalizacja, natomiast na poziomie regionalnym zostały określone w strategiach rozwoju regionów lub regionalnych strategiach innowacji. Inteligentne specjalizacje w dużym stopniu będą wpływać na alokację środków publicznych oraz programy wspierające rozwój klastrów. Trzeci poziom rozkładu klastrów obejmuje Klastry Lokalne. Ich cechą jest mobilizacja oddolnego powstawania i angażowania się aktorów klastrów w procesy wspólnego, strategicznego planowania rozwoju oraz definiowania wspólnych przedsięwzięć na poziomie lokalnym. Oprócz tych trzech poziomów, w kształtowaniu polityki klastrowej należy uwzględnić również międzynarodowy wymiar klastrów. 


\section{Instrumenty polityki klastrowej}

Instrumenty wsparcia klastrów są bezpośrednim efektem prowadzonej polityki klastrowej na poziomie Unii Europejskiej, kraju oraz regionu. W perspektywie finansowej 2014-2020 przewidywane są różne instrumenty polityki klastrowej, które są mniej lub bardziej wprost ukierunkowane na stymulowanie rozwoju klastrów. Istnieje także szereg instrumentów, które nie odwołują się wprost do klastrów, ale mogą umożliwić rozwój różnych ich elementów, takich jak wzrost innowacyjności, rozwój instytucji otoczenia biznesu, wzrost powiązań nauka-gospodarka czy realizowanie wspólnych projektów badawczo-rozwojowych przedsiębiorstw i jednostek badawczych. W latach 2014-2020 Unia Europejska w dalszym ciągu wspierać będzie tworzenie i działalność klastrów. Świadczą o tym europejskie dokumenty strategiczne i operacyjne oraz sposoby wsparcia, takie jak m.in. [Klastry... 2014-2020]:

- Strategia Europa 2020, w ramach której szereg tzw. inicjatyw flagowych przewiduje wielowymiarowe wsparcie klastrów jako instrumentu podnoszenia konkurencyjności i innowacyjności europejskich przedsiębiorstw na globalnym rynku. Inicjatywa flagowa Unia Innowacji zakłada wspieranie klastrów klasy światowej oraz przewiduje konsolidację programów wspierających współpracę transgraniczną, w tym m.in. inicjatyw na rzecz rozwoju klastrów. Druga inicjatywa flagowa Polityka Przemysłowa w Erze Globalizacji; nawiązując do klastrów i sieci jako narzędzi zwiększających konkurencyjność przemysłu i wpływających na podniesienie innowacyjności przedsiębiorstw, wskazuje, że polityka klastrowa powinna skupić się na niwelowaniu niedoskonałości rynku i budowaniu pomostu pomiędzy przemysłem a instytucjami badawczymi. Należy wspierać klastry w ramach inteligentnych specjalizacji oraz rozwijać klastry konkurencyjne w skali światowej.

- Certyfikacja klastrów prowadzana przez European Secretariat for Cluster Analysis. Klastry mogą dobrowolnie poddać się procesowi certyfikacji i uzyskać certyfikat jakości zarządzania.

- Wsparcie współpracy międzynarodowej klastrów i firm klastrowych. Jest realizowane poprzez porozumienia Memoranda of Understanding i misje gospodarcze. Misje gospodarcze są organizowane dla przedstawicieli organizacji zarządzających klastrami oraz dla małych i średnich przedsiębiorstw działających w klastrach. Mają one na celu internacjonalizację firm poprzez klastry i stanowią dla europejskich przedsiębiorstw okazję do znalezienia partnerów technologicznych i biznesowych, jak również do wejścia na zagraniczne rynki.

- Strategiczne partnerstwa klastrów European Strategic Cluster Partnerships (ESCP). Ich celem jest współpraca klastrów i sieci przekraczająca granice geograficzne i sektorowe, która ma doprowadzić do powstania nowych łańcuchów wartości obejmujących firmy z różnych sektorów, jak również zapewnić lepsze wsparcie małych i średnich przedsiębiorstw w warunkach konkurencji globalnej. 
Ponadto klastry są uwzględnione w programach ramowych Unii Europejskiej, m.in. w ramowym programie badań i rozwoju Unii Europejskiej HORIZON 2020. Program finansuje projekty realizowane w konsorcjach, które mogą istnieć w ramach klastrów. Finansowanie obejmuje przede wszystkim wsparcie projektów opierających się na trzech priorytetach: doskonała baza naukowa, wiodąca rola w przemyśle i wyzwania społeczne. Program finansuje działania wspierające idee Innowacyjnej Unii w Europie 2020; inicjatywa ma na celu zapewnienie konkurencyjności Europy w świecie [Horizon 2020]. W zakresie badań i innowacji ma przyczynić się do wzrostu gospodarczego i zwiększenia zatrudnienia w państwach Unii Europejskiej. Inny program ramowy Unii Europejskiej wskazujący na rolę i znaczenie klastrów w rozwoju społeczno-gospodarczym, a także konieczność ich wsparcia, to program COSME [ 2014]. Realizacja programu ma na celu ułatwienie dostępu do finansowania dla małych i średnich przedsiębiorstw, kreowanie odpowiedniego środowiska sprzyjającego tworzeniu nowych przedsiębiorstw, wspieranie przedsiębiorczości w Europie i wzmacnianie konkurencyjności europejskiej gospodarki oraz wspieranie internacjonalizacji małych i średnich przedsiębiorstw. W ramach programu COSME realizowany będzie Cluster Excellence Programme, który będzie wspierał benchmarking mający na celu zwiększenie liczby klastrów posiadających certyfikaty w zakresie zarządzania. Program będzie także wspierał szkolenia, które będą adresowane do organizacji zarządzających klastrami zaangażowanych we wspólne projekty przemysłowe oraz zainteresowanych usprawnieniem procedur zarządzania i podniesieniem swoich umiejętności w tym zakresie.

Przedstawione instrumenty i sposoby wspierania rozwoju klastrów wskazują, że Unia Europejska popiera ideę klastrów. Zakłada się, że Europa osiągnie przewagę konkurencyjną w kluczowych dziedzinach, m.in. poprzez rozwój klastrów. W związku z tym Unia Europejska popiera i podejmuje szereg działań i inicjatyw zmierzających do tworzenia i wsparcia ich rozwoju.

Na poziomie krajowym, z uwagi na pozytywne efekty wynikające $\mathrm{z}$ funkcjonowania klastrów, władze publiczne również podejmują szereg działań zmierzających do ich rozwoju. Z punktu widzenia kraju są to korzyści wynikające przede wszystkim z rozwoju innowacji i unowocześnienia technologicznego gospodarki. Klastry działające w danym kraju przyczyniają się do wzrostu gospodarczego i większej konkurencyjności gospodarki. W nowej perspektywie finansowej 2014-2020 bezpośrednie centralne wsparcie klastrów w Polsce przewidziano m.in. w Programach Operacyjnych:

- Programie Operacyjnym Inteligentny Rozwój (PO IR),

- Programie Operacyjnym Polska Wschodnia (PO PW).

Program Operacyjny Inteligentny Rozwój jest jednym z sześciu programów krajowych. W całości jest realizowany w ramach Europejskiego Funduszu Rozwoju Regionalnego. Program ten daje możliwość finansowania klastrów o istotnym potencjale dla rozwoju gospodarki i konkurencyjnych w skali międzynarodowej. Z Programu Operacyjnego Inteligentny Rozwój środki finansowe przeznacza się 
przede wszystkim na internacjonalizację, czyli umiędzynarodowienie działalności polskich przedsiębiorstw, na rozwój inwestycji i konkurencyjności małych i średnich przedsiębiorstw oraz działalności B+R+I [Program Operacyjny Inteligentny Rozwój 2015].

Uzupełnieniem wsparcia na poziomie krajowym będą działania realizowane w ramach Programu Operacyjnego Polska Wschodnia, skierowane do beneficjentów pięciu województw Polski Wschodniej: lubelskiego, podkarpackiego, podlaskiego, świętokrzyskiego i warmińsko-mazurskiego. Środki z tego funduszu w głównej mierze przeznaczone będą na rozwój innowacyjnej przedsiębiorczości oraz na ważne, z punktu widzenia spójności i dostępności terytorialnej makroregionu, inwestycje w komunikację miejską, drogi i kolej [Program Operacyjny Polska Wschodnia 2015]. Program ten zakłada także wsparcie podmiotów wchodzących w skład inicjatywy klastrowej w celu wzrostu ich konkurencyjności i innowacyjności.

Analogicznie do okresu programowania 2007-2013 instrumenty wspierające rozwój klastrów założono również w Regionalnych Programach Operacyjnych. Wsparcie udzielane w ramach programów operacyjnych będzie komplementarne do wsparcia w ramach Programu Operacyjnego Innowacyjny Rozwój oraz uzupełniać będzie wsparcie Programu Operacyjnego Polska Wschodnia w zakresie powiązań kooperacyjnych. Środki finansowe będą trafiać do tych klastrów, które zaliczać się będzie do regionalnych klastrów kluczowych, oraz do tych, które związane są z inteligentnymi specjalizacjami regionu. Regionalne Programy Operacyjne stanowią istotne narzędzie realizacji strategii rozwoju poszczególnych województw. Poprzez środki pochodzące z Regionalnych Programów Operacyjnych poszczególne województwa realizować będą cele i kierunki rozwoju założone w swoich strategiach rozwoju. Priorytetem będzie zawsze zwiększenie konkurencyjności a w konsekwencji zmniejszenie bezrobocia. W odróżnieniu od poprzedniej perspektywy wsparcie w ramach Regionalnych Programów Operacyjnych będzie udzielane z dwóch funduszy strukturalnych: Europejskiego Funduszu Rozwoju Regionalnego oraz Europejskiego Funduszu Społecznego. Środki pochodzące z Funduszy Europejskich zarówno na poziomie krajowym, jak i regionalnym muszą być przeznaczone na realizację działań zgodnych z wytyczonymi przez Unię Europejską obszarami tematycznymi [Programowanie perspektywy finansowej 2014-2020].

\section{Zakończenie}

Klastry są narzędziem poprawy konkurencyjności gospodarki zarówno na poziomie krajowym, regionalnym, jak i lokalnym. Unia Europejska dostrzegając potencjał i znaczenie klastrów w rozwoju regionu, podejmuje szereg inicjatyw wspierających proces ich tworzenia i sprawnego funkcjonowania. Szczególny wzrost liczby stworzonych klastrów nastąpił w minionej perspektywie budżetowej Unii Europejskiej na lata 2007-2013. W ramach poprzednich środków finansowych można było ubie- 
gać się o dofinansowanie dla klastrów m.in. z programu PO IG z działania 5.1. „Wspieranie rozwoju powiązań kooperacyjnych o znaczeniu ponadregionalnym”, Regionalnych Programów Operacyjnych i PO RPW z działań 1.3 „Wspieranie innowacji” i 1.4 „Promocja i współpraca. Komponent współpraca”. W okresie finansowania na lata 2014-2020 stworzono nowe programy, a w ramach nich działania, które będą wspierać nowe i już istniejące klastry. Specjalne programy dla klastrów dofinansowane będą z Programu Operacyjnego Inteligentny Rozwój (PO IR), Programu Operacyjnego Polska Wschodnia (PO PW) i Regionalnych Programów Operacyjnych. Środki z Programu Operacyjnego Inteligentny Rozwój zostaną wykorzystane na działalność klastrów wpływających na rozwój gospodarki, a także na zwiększenie ich międzynarodowej konkurencyjności. Wsparcie finansowe z drugiego programu będzie przeznaczone na tworzenie klastrów ponadregionalnych na obszarach pięciu województw biorących udział w PO PW. Natomiast z Regionalnych Programów Operacyjnych fundusze otrzymają nowe lub już działające grona, które mają ogromne znaczenie dla danego regionu.

Jak wynika z dokonanego przeglądu instrumentów wsparcia, podstawowym celem polityki klastrowej w latach 2014-2020 będzie wzmocnienie innowacyjności i konkurencyjności polskiej gospodarki w oparciu o intensyfikację współpracy, interakcji i przepływów wiedzy w ramach klastrów oraz wspieranie rozwoju strategicznych specjalizacji gospodarczych. Na poziomie krajowym i regionalnym najistotniejszym elementem, na który skierowane zostanie wsparcie, są inteligentne specjalizacje. Środki finansowe zostaną w głównej mierze skierowane na te dziedziny życia gospodarczego lub nauki, które stanowią nową, rozwojową specjalizację gospodarczą, która opiera się na wykorzystaniu unikalnych zasobów regionów, połączeniu różnych branż, zastosowaniu innowacyjnych rozwiązań technologicznych. Inteligentne specjalizacje mają na celu podniesienie konkurencyjności regionów. W polityce klastrowej dla efektywniejszego wykorzystania wsparcia przyjęto trójstopniowy rozkład klastrów: Kluczowe Klastry Krajowe, Kluczowe Klastry Regionalne i Klastry Lokalne. Taka klasyfikacja klastrów pozwoli na efektywniejsze wykorzystanie wsparcia i osiągnięcie efektu końcowego na wysokim poziomie. Wsparcie w ramach Regionalnych Programów Operacyjnych będzie udzielane z dwóch funduszy strukturalnych: Europejskiego Funduszu Rozwoju Regionalnego oraz Europejskiego Funduszu Społecznego. Dotychczas środki finansowe były przyznawane dla koordynatorów klastrów, którzy w następnej kolejności prowadzili działania na rzecz członków klastra. Ta forma finansowania zostanie utrzymana, jednak zostanie wprowadzona także nowa metoda, polegająca na bezpośrednim wsparciu firm i instytucji będących członkami klastra na realizację ich celów.

Oprócz krajowych programów, o dofinansowanie na działalność klastrów będzie można ubiegać się $\mathrm{w}$ ramach dwóch unijnych programów: Horyzont 2020 i COSME. 


\section{Literatura}

Brodzicki T., Szultka S., Tamowicz P., Wojnicka E., 2004, Polityka wspierania klastrów. Najlepsze praktyki. Rekomendacje dla Polski. Niebieskie księgi. Rekomendacje nr 11, IBnGR.

COSME, 2014, www.ec.europa.eu/enterprise/initiatives/cosme/index_en.htm (21.11.2013).

Dzierżanowski M. (red.), 2012, Kierunki i założenia polityki klastrowej w Polsce do 2020 r. Rekomendacje Grupy roboczej ds. polityki klastrowej, PARP, Warszawa.

Dzierżanowski M., 2006, Raport otwarcia nt. polskiej polityki klastrowej, opracowany na potrzeby prac Grupy roboczej ds. polityki klastrowej w ramach przedsięwzięcia Polskiej Agencji Rozwoju Przedsiębiorczości „Polskie klastry i polityka klastrowa”, PARP, Warszawa.

Gorynia M., Jankowska B., 2000, Klastry a konkurencyjność i internacjonalizacja przedsiębiorstw wyniki badań empirycznych, [w:] Kotowicz-Jawor J. (red.), GOW-wyzwanie dla Polski, PTE, Warszawa.

Hefner K., Klemens B., 2008, Funkcjonowanie inicjatyw klastrowych jako czynnik rozwoju przedsiębiorczości w regionie, [w:] Korenik S., Przybyła Z. (red.), Wspótczesne problemy polityki ekonomicznej, Uniwersytet Ekonomiczny we Wrocławiu, Jelenia Góra.

Horizon 2020, ww.kpk.gov.pl/pliki/12784/1_H2020.pdf (7.10.2013).

Klastry w nowej perspektywie finansowej 2014-2020www.pi.gov.pl/PARP/chapter_86197 (13.03.14).

Kowalski A.M., 2013, Znaczenie klastrów dla innowacyjności gospodarki w Polsce, Oficyna Wydawnicza SGH, Warszawa.

Koszarek M. (red.), 2011, Inicjatywy klastrowe: skuteczne działanie i strategiczny rozwój, PARP, Warszawa.

Plawgo B., 2014, Benchamrking klastrów w Polsce - edycja 2014. Raport ogólny, PARP, Warszawa.

Porter M., 2000, Location, competition, and economic development: local clusters in global economy, Economic Development Quartely, Thousand Oaks.

Program Operacyjny Inteligentny Rozwój 2014-2020, 2015, Ministerstwo Infrastruktury i Rozwoju, Departament Konkurencyjności i Innowacyjności Warszawa.

Program Operacyjny Polska Wschodnia 2014-2020, 2015, Ministerstwo Rozwoju Regionalnego, Warszawa.

Programowanie perspektywy finansowej 2014-2020 - Założenia Umowy Partnerstwa; przyjęte przez Radę Ministrów 15 stycznia 2013 r., Ministerstwo Rozwoju Regionalnego.

Programowanie perspektywy finansowej 2014-2020, 2015, Uwarunkowania strategiczne Departament Koordynacji Polityki Strukturalnej, Ministerstwo Rozwoju Regionalnego.

Rozporządzenie Parlamentu Europejskiego i Rady (UE) nr 1303/2013 z 17 grudnia 2013 r. 